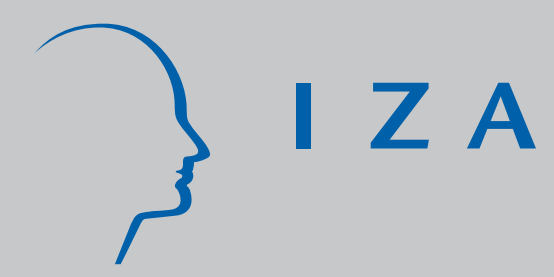

IZA DP No. 780

Temporary Contracts and Employee Effort

Axel Engellandt

Regina T. Riphahn

May 2003 


\title{
Temporary Contracts and Employee Effort
}

\author{
Axel Engellandt
}

University of Basel

Regina T. Riphahn

University of Basel, CEPR, DIW Berlin and IZA Bonn

\section{Discussion Paper No. 780 \\ May 2003}

\author{
IZA \\ P.O. Box 7240 \\ D-53072 Bonn \\ Germany \\ Tel.: +49-228-3894-0 \\ Fax: +49-228-3894-210 \\ Email: iza@iza.org
}

This Discussion Paper is issued within the framework of IZA's research area Mobility and Flexibility of Labor. Any opinions expressed here are those of the author(s) and not those of the institute. Research disseminated by IZA may include views on policy, but the institute itself takes no institutional policy positions.

The Institute for the Study of Labor (IZA) in Bonn is a local and virtual international research center and a place of communication between science, politics and business. IZA is an independent, nonprofit limited liability company (Gesellschaft mit beschränkter Haftung) supported by the Deutsche Post AG. The center is associated with the University of Bonn and offers a stimulating research environment through its research networks, research support, and visitors and doctoral programs. IZA engages in (i) original and internationally competitive research in all fields of labor economics, (ii) development of policy concepts, and (iii) dissemination of research results and concepts to the interested public. The current research program deals with (1) mobility and flexibility of labor, (2) internationalization of labor markets, (3) welfare state and labor market, (4) labor markets in transition countries, (5) the future of labor, (6) evaluation of labor market policies and projects and (7) general labor economics.

IZA Discussion Papers often represent preliminary work and are circulated to encourage discussion. Citation of such a paper should account for its provisional character. A revised version may be available on the IZA website (www.iza.org) or directly from the author. 
IZA Discussion Paper No. 780

May 2003

\section{ABSTRACT}

\section{Temporary Contracts and Employee Effort}

Temporary contracts provide employers with a tool to screen potential new employees and have been shown to provide "stepping stones" into permanent employment for workers. For both reasons workers on temporary contracts have an incentive to provide more effort than permanent employees. Using indicators for unpaid overtime work and absences taken from the Swiss Labor Force Survey we present evidence that temporary workers indeed provide higher effort than permanent employees: Their probability of working unpaid overtime exceeds that of permanently employed workers by 60 percent. We show the heterogeneity of this effect across different types of temporary contracts, investigate differences between men and women, and discuss the relevance of adverse selection into temporary employment.

JEL Classification: J24, J41, M50, C25

Keywords: temporary work, contract-based incentives, absenteeism, overtime, moral hazard, career concerns

Corresponding author:

Regina T. Riphahn

WWZ

University of Basel

Post Box 517

4003 Basel

Switzerland

Email: regina.riphahn@unibas.ch 


\section{Introduction}

Contract-based incentives are of key interest not only for behavioral sciences such as personnel economics, but also for active human resources management. ${ }^{1}$ An important characteristic of employment contracts is whether they are permanent or temporary. Since temporary employment as a share of total employment recently has risen in a number of countries it has garnered increased scientific attention (cf. OECD 2002, Booth et al. 2002a). However, researchers mostly address questions relating either to the macroeconomic impact of temporary employment on unemployment and labor turnover, ${ }^{2}$ or to differences of job (e.g. wage, training) and worker characteristics in permanent versus temporary contracts. ${ }^{3}$

This appears to be the first study to raise the question of whether there are measurable behavioral responses connected to holding permanent versus temporary employment contracts. The incentives behind such responses are hypothesized to derive from the character of temporary jobs as stepping stones to generally preferable permanent jobs, a role that is confirmed in empirical studies: ${ }^{4}$ If temporary employment can offer access to desirable permanent contracts, temporary employees have an incentive to display high levels of effort.

The issue of behavioral responses to temporary contracts is related to an empirical literature which confirms contract-based incentives in a variety of other areas. The studies look at effort responses to probation and employment protection, analyze the response of absenteeism to sick-leave regulations, and describe responses to monitoring intensity. ${ }^{5}$

Using data from the Swiss Labor Force Survey (SLFS) we compare the behavior of

\footnotetext{
${ }^{1}$ The subsequent discussion of contract-based incentives will exclude payment issues.

${ }^{2}$ See e.g. OECD 1999, Cahuc and Postel-Vinay 2002, Dolado et al. 2002, Holmlund and Storrie 2002, and Blanchard and Landier 2002.

${ }^{3}$ See e.g. Morries and Vekker 2001, OECD 2002 and Segal and Sullivan 1997.

${ }^{4}$ A summary of that literature is provided by OECD 2002, pp.160-161.
} 
individuals in permanent and temporary contracts. The SLFS - a rotating panel dataset contains information on workers' current contract and on effort indicators such as absenteeism and unpaid overtime work. We investigate the overall evidence for incentive effects of temporary contracts as well as their heterogeneity across effort indicators and worker groups.

This study adds to the literature in several regards. First, it continues the micro-level analysis of temporary contracts initiated by Booth et al. (2002b). That study examined whether temporary contracts deserve to be considered as "stepping stones." The authors confirm for the United Kingdom that a large proportion of workers on temporary contracts move on to permanent contracts with higher wages and fringe benefits. They also show that high effort among temporary workers is positively correlated with the probability of career advancement.

Second, we provide empirical evidence of the extent of contract related incentive effects, an issue neglected in prior discussions. We carefully describe the behavior of individuals employed in different types of temporary contracts to clarify that there are important heterogeneities. Finally, we present evidence for the interesting case of Switzerland, a country similar to the United Kingdom and the United States in that employment protection is limited, and a country about which too little is known so far.

Our results confirm that workers respond to contract related incentives, as individuals on temporary contracts are significantly more likely to provide unpaid overtime work. On average their overtime work propensity exceeds that of permanently employed workers by 60 percent. We investigate the relevance of adverse selection into temporary employment and describe the heterogeneity of our findings across different types of temporary employment.

The paper proceeds as follows: Section 2 describes the relevant literature and

\footnotetext{
${ }^{5}$ See e.g. Ichino and Riphahn (2001), Barmby et al. (1991), and Nagin et al. (2002).
} 
formulates the hypotheses tested in our empirical analysis. Section 3 describes the data and empirical strategy, and section 4 presents the results. A conclusion is provided in section 5 .

\section{Incentives, Prior Empirical Evidence, and Hypotheses}

Since the incentive effect of temporary contracts has not been investigated before, we first review related studies and then discuss our hypotheses. The effect of contract-based incentives on employee behavior has been addressed in the empirical literature on the role of employment protection as well as in research on sick-pay related moral hazard.

The studies evaluating the incentive effects of employment protection utilize institutional regulations to identify the relevant effects. Ichino and Riphahn (2001) find strong increases in absenteeism among Italian bank employees when probation periods end and employment protection sets in. Riphahn and Thalmaier (2001) confirm similar absenteeism responses to the end of probationary contracts among German employees. Jimeno and Cortes (1996) investigate the effect of low employment protection in Spanish temporary employment on absenteeism: Those without employment protection provide significantly higher levels of effort compared to workers in secure permanent contracts.

The hypothesis that sick-pay provides incentives for opportunistic behavior has been confirmed in a broader literature. Barmby et al. (1991) show that sick-pay regulations yield clear employee responses. Johansson and Palme (1996, 2002) describe the decline in absenteeism among Swedish men after a reduction of sick-pay, and Barmby (2002) finds that workers reduce absences more when sick-pay is low relative to earnings.

Similar to probationary periods, employment protection legislation, and sick-pay provisions, the duration of workers' employment contract may generate effort responses. These can be evaluated by comparing the behavior of workers on temporary and permanent contracts. As long as temporary employment contracts are less attractive than permanent ones 
temporary workers have an incentive to provide high levels of effort. ${ }^{6}$ A first reason is that firms tend to use temporary employment to screen potential permanent employees prior to committing to a binding contract. So if temporary workers want to obtain a permanent employment contract they need to pass this employer screening.

Second, there is considerable direct evidence that temporary contracts serve as stepping stones into more attractive employment contracts - also with other than the current employer. Booth et al. (2002b) confirm for their U.K. sample that over a period of 7 years about 38 percent of all workers observed on fixed-term contracts move on to permanent employment after the fixed-term contract expires. ${ }^{7}$ Interestingly, the authors confirm a positive correlation between a worker's effort as measured by the number of unpaid hours of overtime work, and the probability of moving on to a permanent contract.

However, these incentive mechanisms may not characterize all types of temporary contracts in the same way, Booth et al. (2002b) distinguish jobs which are temporary by nature ("seasonal and casual employment") from those which could just as well be filled by permanent employees ("fixed term contracts"). Employees in these contract categories differ significantly in their transition rates to permanent employment, in the long run wage effects of past temporary employment, as well as in wages and job satisfaction.

Another interesting issue concerns the difference between male and female temporary workers. Booth et al. (2002b) argue - similar to Lazear and Rosen (1990) - that women may seek temporary employment because this better matches their high propensity to move on to non-market employment. Therefore women may more frequently self-select in non-screening types of temporary employment than men. This would suggest that women in temporary

${ }^{6}$ OECD (2002) estimates show significant wage penalties for temporary employment in regressions that control for individual and job characteristics, separately for 13 European countries. This finding seems to be representative of the literature and is easily confirmed in our data as well. 
employment ceteris paribus may provide less effort than men, as men are more likely to seek career advancement ("housewife effect").

Additional aspects may affect behavioral differences between the sexes: Discrimination might influence the selection of individuals into fixed term versus permanent jobs. If for given ability men are more likely to find permanent employment, then - on average - women in temporary employment should be of higher ability. If high ability is correlated with a career orientation then these high ability women may respond to incentives and provide additional effort. ${ }^{8}$ In this case women in temporary employment ceteris paribus may provide more effort than men ("resilience effect"). However, the conclusion that the experience of discrimination results in the subsequent provision of high effort may not be convincing: If high ability has not been rewarded in the past high effort now may be in vein as well ("frustration effect"). These are three gender-specific mechanisms where the first and the last should cause lower and the second higher effort among women compared to men. Below we investigate the empirical evidence on this question.

Overall our empirical analysis seeks to test the following hypotheses:

H1: Workers in temporary employment provide more effort compared to workers in permanent contracts.

H2: The effort response of temporary workers to the incentives inherent in temporary employment contracts varies because of the heterogeneity in the incentive itself: Seasonal and casual workers may not be subject to the same level of ability screening as substitute workers on jobs that might become permanent. We expect heterogeneity in effort response by type of temporary contract.

H3: We hypothesize that males and females differ in their response to temporary employment incentives.

\footnotetext{
7 In our data we 26 percent of those temporarily employed in one year move on to permanent employment in the next period.

${ }^{8}$ Booth et al. (2002c) also discuss active discrimination on the part of the employer as an explanation for differences between the sexes.
} 


\section{Data and Empirical Strategy}

\subsection{Dataset and Sample}

The data for our analysis are taken from six annual waves (1996 - 2001) of the Swiss Labor Force Survey (SLFS). The SLFS is a telephone survey among randomly chosen individuals aged 15 and above. It does not cover foreign workers without a permanent residence permit. The typical annual survey samples $16-18,000$ households. The SLFS is a rotating panel where every individual is interviewed up to five times. The questionnaires cover sociodemographic indicators, employees' type of contract, and measures of effort.

Pooling the observations from six annual surveys yields 103,005 observations. We restrict our sample to non-self-employed individuals in full-time employment, who are not in an apprenticeship or in military service. We drop individuals of retirement age (men above age 65 , women above 63) and a few observations with missing values on key variables. Our sample covers 33,945 person-year observations, representing 10,497 different male and 5,411 different female workers, with on average 2.1 annual observations per person.

\subsection{Key Dependent and Explanatory Variables}

We consider two effort indicators as dependent variables, which are established in this literature: The first measures whether the worker provides unpaid overtime hours, ${ }^{9}$ the second describes whether a person missed work in the week prior to the survey due to illness, accident, personal or family matters, or "other" reasons. ${ }^{10}$ Both measures are binary variables.

The key explanatory variable indicates whether the individual works on a temporary

\footnotetext{
${ }^{9}$ Respondents are asked whether it happens frequently or at least sometimes that they have to work longer hours than spelled out in their contract. If they agree a subsequent question asks whether this is typically remunerated financially, in leisure, or not at all. Those indicating that overtime work is typically not remunerated provide unpaid overtime work.

${ }^{10}$ Similar indicators were used by Booth et al. (2002b) in the case of overtime and Jimeno and Cortes (1996) for absences.
} 
contract. 4.4 percent of all employees in our sample are temporarily employed. This figure differs from the about ten percent share presented by OECD (2002) for Switzerland; the difference is most likely due to the different selection of the samples. ${ }^{11}$ Based on the sampling rules applied by OECD (2002) Switzerland's temporary employment share is at the OECD average. While some countries experienced severe fluctuations in the share of their temporary employment over time, the Swiss figure remained stable during the six years of our data between a maximum of 4.9 percent in 1996 and the lowest value of 3.7 percent in 2000 .

Based on the SLFS information on the type of temporary contract we distinguish four contract types and coded a fifth describing observations with missing contract type information. The four contract types describe (i) seasonal and casual employment, (ii) public sector sponsored employment programs, (iii) internships, and (iv) "advanced temporary contracts" combining temporary substitute workers, fixed term project work, probationary employment, temporary employment agency workers, and "other" temporary contracts. ${ }^{12}$ Public sector sponsored programs are designed to reintegrate previously unemployed workers in the labor market. Internships are temporary contracts with typically low or no pay, where the intern intends to learn about the workings of a company or agency. We expect that the incentive to provide effort is highest among those with the highest probability of company screening, i.e. categories (iv) and (iii), and lowest among groups (ii) and (i) where workers are either unlikely to reapply for employment or where promotions are not possible.

Table 1 presents the characteristics of individuals employed in permanent and temporary contracts. It yields differences in a variety of dimensions: Temporary work is more frequent among the young, among females, non-married, and foreign workers. The

\footnotetext{
11 The OECD (2002, Chart 3.1) measures include part-time workers, apprentices and self-employed workers, and do not seem to impose age restrictions.
} 
educational patterns are nonlinear in that temporary workers are more likely to be in the lowest and the highest educational categories compared to those employed permanently. The distribution of workers across firm size categories does not seem to differ by contract type, but permanent workers have much longer tenure.

Given the availability of panel data for some of our observations it is interesting to measure the probability of remaining in temporary employment over time. The period-toperiod probability of leaving temporary employment for a permanent job amounts to 26 percent in our sample. The reverse probability of leaving permanent employment for a temporary job is low at 0.9 percent. ${ }^{13}$

Given that permanent and temporary contracts differ in a number of dimensions it is interesting to describe effort levels by contract type. The first row in Panel A of Table 2 indicates that 20.6 percent of all those employed on permanent contracts and 27.7 of those on temporary contracts have worked unpaid overtime. The first row in Panel B shows that the absence rate among those in permanent contracts exceeds that among temporary workers by about 44 percent. Thus the aggregate measures agree with our expectation of higher effort among temporary employees. These differences are similar when we evaluate the evidence by sex, where generally men appear to provide higher levels of effort than women.

The last five columns of Table 2 describe mean effort by type of temporary employment contract. For both indicators, we find the highest effort levels among those in contract categories (iii) and (iv). ${ }^{14}$ Also when disaggregating by sex effort seems to be lowest among those in public programs.

\subsection{Empirical Strategy}

\footnotetext{
${ }^{12}$ Varying formulations of the contract categories across the six annual questionnaires did not allow us to describe these contract types more finely in a consistent manner over time.

${ }^{13}$ Both figures represent lower bounds of the true shares because we do not observe the transitions of those individuals who drop out of the survey due to panel rotation.
} 
The purpose of our analysis is to test the hypotheses derived in section 2 . Hypothesis 1 (H1) claims that workers in temporary contracts provide more effort than those permanently employed. This is tested by regressing our effort outcomes on an indicator of temporary employment in random effects probit models. To ensure that the measured outcomes are not due to composition effects, the model considers control variables describing the individual worker (age, sex, marital status, nationality, health, level of education), the job (tenure, firm size, industry, occupation), and survey year effects. Table 3 provides descriptive statistics of the explanatory variables. We provide the results of random effects probit estimates when the control for individual-specific unobserved heterogeneity improved the model, and discuss standard probit results with robust standard errors otherwise.

In step 2 of the analysis we test $\mathrm{H} 2$, which proposes that effort responses of temporary workers should vary by type of contract. We expect higher effort among interns and those on advanced temporary contracts. This is formally tested by substituting a set of type of contract indicators for the overall indicator of temporary employment in our models.

The last step of the analysis investigates differences in responses to incentives by gender. We first add interactions between the temporary contract and female sex indicators and then discuss more refined estimation approaches.

\section{Results}

The results of the "baseline" regressions for the overtime and absence indicators are presented in Table 4. The random effects control significantly improved the model fit in the overtime model, only. Overall the regression results are robust to the choice of the estimator.

The temporary contract indicator yields the expected coefficient in the model for

${ }^{14}$ The high effort levels of workers in the last column of Table 2 with missing contract type information are surprising, but may be correlated with the high educational level in this group (figures not presented). 
overtime work: Individuals on temporary jobs are significantly more likely to work unpaid overtime hours than individuals on permanent contracts. In fact, controlling for the other variables the difference in the predicted probabilities even exceeds that presented in Table 2: The regression suggests that holding everything else constant the probability of overtime work under a temporary contract exceeds that under a permanent contract by 60.49 percent (see bottom row and notes of Table 4), which compares to a 33.85 percent difference in the unadjusted data in Table 2.

The other results indicate that the propensity to work unpaid overtime increases significantly with age and education, it is higher for males, Swiss nationals, for married individuals, and for those free of grave health shocks. ${ }^{15}$ Also, overtime work is correlated with tenure, firm size, occupation and industry. Joint coefficient tests yielded significant overall effects for the sets of age, tenure, firm size, occupation, and industry indicators.

In contrast to the estimation of overtime work, the model for absences does not yield a statistically significant difference by contract status. While the negative coefficient indicates a lower absence probability for those on temporary contracts, the coefficient is insignificant. This finding is robust across specifications and estimators, and remains unchanged when more detailed indicators and interactions of the temporary work indicator are considered. ${ }^{16}$

We conclude that in our data temporary workers differ from permanently employed colleagues with respect to unpaid overtime work but not regarding absences. This can be interpreted to mean that either temporary workers do not make a special effort to avoid

\footnotetext{
15 The measure for a health shock is available only for the 1998 - 2001 surveys and describes whether a worker has ever experienced a health based work absence of more than half a year.

${ }^{16}$ Given the very small share of absence events in the data the imprecise estimate may be due to the small number of observations in the temporary contract group (only 12 temporary workers experienced a work absence). Since logit and probit models generate different results when there is an extreme split in the dependent variable, we estimated the models with logit estimators as well. The outcome of an insignificant difference for the absence outcome between temporary and permanent contract workers remains robust.
} 
absences or permanent workers miss work already at very low levels. By international comparison Swiss absenteeism rates are indeed very low: Barmby et al. (2002) compare absence rates for 9 European countries: Swiss workers are least likely to miss work. The Swiss absence rate of 1.8 is far below the international average of 3.2. This suggests that in Switzerland absenteeism is not a dimension in which temporary workers can signal their motivation. We therefore focus our further analysis on the overtime work indicator, for which hypothesis 1 cannot be rejected.

Next, we investigate the heterogeneity of effort responses across the different types of temporary employment. The estimation results are presented in Table 5. The categorical indicators of the type of contract are jointly significant at the 1 percent level. The coefficients confirm our expectations in that interns and workers on advanced temporary contracts are more likely to provide extra work effort, with a highly significant effect for the latter. The predicted effects indicate an increase in the probability of overtime work by 2.3 and 4.6 percentage points for interns and "advanced" temporary workers, respectively. These are sizeable effects given a baseline probability of overtime work of 6.5 percent. Even when controlling for covariates, workers on public programs are less likely to work overtime. Thus hypothesis 2 cannot be rejected, there is significant heterogeneity in the effort response of temporary workers.

Finally, we investigate potential differences between the sexes as suggested by hypothesis 3 . The baseline model for unpaid overtime work in Table 4 yields a sizeable significant negative coefficient for the indicator of female sex: Among all workers females provide less unpaid overtime work than men. We are interested in the differences for temporary contracts and reestimated the model after adding an interaction for temporary contract and female sex. The result (see Table 6, column 1) yields an imprecisely estimated coefficient of small magnitude. Thus we find no significant difference between the sexes. 
In section 3 we discussed alternative hypotheses regarding the differences in malefemale effort responses to working on temporary contracts. If both, the factors causing higher and lower effort are effective, the net effect might be that females do not differ from males. To investigate this possibility we estimate refined models with additional interaction terms.

In column (2) of Table 6 we present the effect of interactions of the type of temporary contract and female sex. These coefficients are jointly significant at the ten percent level and show that the direction of the effort effect for women runs counter to the effect estimated for men and thereby counter to $\mathrm{H} 2$ : Female interns are significantly less likely to provide unpaid overtime work compared to male interns. Female seasonal and casual workers are significantly more likely to work overtime compared to their male colleagues. This weakly suggests that women respond less to career incentives than men.

A possible explanation may be that female workers accumulate less overtime in general because due to family obligations their time constraints are particularly binding. We investigated whether this affects the effort responses to temporary work by controlling for interactions with marital status and even an indicator of whether there are children to care for in the household. ${ }^{17}$ These estimations did not yield statistically significant results and we cannot reject the hypothesis that in our sample the family background of women has no effect on their response to incentives. ${ }^{18}$

\section{Adverse Selection into Temporary Contracts}

A potentially important issue not addressed so far concerns the exogeneity of the

\footnotetext{
17 The data does not allow us to guarantee that the women in our sample are the mother of the children but it is likely to be true in most cases.

${ }^{18} \mathrm{We}$ also investigated whether women are on average more likely to end up in temporary employment than men with the same characteristics. If the selection mechanism works different for the two sexes this may affect our results. However, the sex indicator has no significant impact on the probability of being temporarily
} 
temporary contract indicator itself. This problem was explicitly or implicitly ignored in prior studies of temporary workers (Jimeno and Cortes 1996, Booth et al. 2002b). It is possible that those who end up in temporary employment are not a random draw from the population and that this selection affects the estimates. Given the detailed controls for human capital and job characteristics in our model it is unlikely that a selection based on observable characteristics causes a bias in our estimation.

However, the results may be biased if unobservable factors determine the selection into temporary contracts and if these are correlated with our dependent variable. On the one hand temporary employees might be a "negative" selection of workers with lower ability or motivation, accepting the wage penalty connected to this type of employment. In that case we would expect a weaker effort response to contract-based incentives compared to an average worker, and our estimates would provide an underestimate of the true effort response.

Alternatively one might argue that temporarily employed workers are a "positive" selection of workers with below average risk-aversion, who accept temporary wage penalties and the challenge of active screening (e.g. as trainees) to qualify for better positions and in expectation of later rewards. In this case our estimates would exaggerate the true effect.

If unobserved characteristics cause selection into temporary employment, the panel nature of our data helps to investigate their impacts: If temporary workers as a group differ systematically from permanent employees there should be a noticeable difference in behavior of those temporary workers who just became permanent compared to those who were permanently employed throughout. We investigate this hypothesis by adding an indicator to the baseline model of Table 4 which describes whether a person who is currently permanently employed was a temporary employee in the preceding period.

The results are presented in Table 7 (column 1). The overall temporary contract employed, neither overall nor for the different types of contracts when looked at separately. 
coefficient is hardly affected by the additional control and the lagged indicator of prior temporary employment status has an insignificant positive coefficient. Thus once previously temporarily employed workers are on a permanent contract their effort does not differ significantly from that provided by other permanently employed workers. This provides evidence against endogenous selection into temporary employment.

One could alternatively argue that high effort among temporary workers is driven by a group of "positively selected" high performers. The results in Table 7(1) yield that those who later work on permanent jobs still provide (insignificantly) more effort than other permanent employees. To investigate the relevance of potential "positive selection" for our results we additionally compare the effort of temporary workers who do and do not reach permanent jobs in the next period. We expect that the latter would be a less "positively selected" group, for whom - if selection is important - the effort response to temporary contracts should be lower. The results in column 2 of Table 7 show highly significant positive coefficients even for those temporary workers who are not moving up to permanent jobs in the next period. Given that the estimated effect is even larger for those who are not moving up than for the "high achievers" who are subsequently employed permanently, this provides further evidence against the suggestion of endogenous selection into temporary employment.

We performed two additional tests for the endogeneity of temporary employment. First, to investigate the potential biasing impact of considering an endogenous "temporary work" indicator on the other coefficients in our model, we reestimated model 1 in Table 4 excluding the temporary contract variable. The marginal effects of the other variables remained largely unchanged, which is unlikely to occur if temporary work were endogenous. Second, the problem could in principle be addressed by using a fixed effects regression. However, the fixed effects logit estimator involves the loss of a sizeable number of observations, in our case 27,141 of 33,945 observations. With the fixed effects estimator we 
again obtain a positive coefficient on the "temporary work" indicator. This positive effect even though imprecisely estimated - again supports the conclusion that the positive correlation between "temporary work" and worker effort is not due to endogeneity.

\section{Summary}

This study analyzes the behavioral correlates of temporary versus fixed term contracts based on six waves of data from the Swiss Labor Force Survey. The results suggest that temporary workers provide significantly more effort: They have a 60 percent higher probability of working unpaid overtime than employees with permanent contracts. Among the temporarily employed effort differs depending on the type of contract: Those in positions with potential for "upward mobility" are significantly more likely to supply high levels of effort.

Interestingly, there was no measurable effect of temporary employment on absenteeism, an indicator typically applied in this literature. We interpret this result in combination with international evidence as indicative of a low overall level of opportunistic absences in Switzerland, which may well be related to the low level of employment protection in this country. In consequence, temporary employees may not be able to signal their characteristics to the employer by low absence rates.

A comparison between males and females yields no significant differences in their overall responses to contract-based incentives in Switzerland. There are only weak indicators for a stronger response of males to such incentives. This similarity of the incentive response of the two sexes would be interesting to examine with different data and for other countries, as it deviates from the findings for the United Kingdom (Booth et al. 2002b).

Our results support the predictions of an incentive-based model of employee signaling behavior in situations of asymmetric information. This can be interpreted either as a behavioral response of those on permanent contracts to the benefits provided by their position, 
or as its mirror image, the response of temporary workers to the lack of such benefits and their incentive to obtain them.

The former interpretation stresses moral hazard in the behavior of permanent employees who may have reduced their effort levels. However, given the nature of our effort indicator, i.e. unpaid overtime work, which describes not just the absence of shirking but the presence of effort above and beyond contractual requirements, the moral hazard interpretation is not convincing. Instead we prefer to emphasize the extra effort of temporary workers who invest in signaling activities. Such behavior - when observed among managers - is considered as an indicator of 'career concerns' which are "concerns about the effects of current performance on future compensation" (Gibbons and Murphy 1992, p.468). The career concerns concept appears appropriate for the situation of temporary employees whose future depends - just as in the case of managers - on being able to establish a reputation with current or potential future employers. In sum, our evidence supports the hypothesis that asymmetric information on employee characteristics provides effective incentives for temporary employees to invest in signaling behaviors. 


\section{References}

Barmby, Tim, Chris Orme and John Treble, 1991, Worker Absenteeism: An Analysis Using Microdata, Economic Journal 101(405), 214-229.

Barmby, Tim A., Marco G. Ercolani, and John G. Treble, 2002, Sickness Absence: An International Comparison, Economic Journal 112(480), F315-F331.

Barmby, Tim, 2002, Worker Absenteeism: A Discrete Hazard Model with Bivariate Heterogeneity, Labour Economics 9(4), 469-476.

Blanchard, Olivier and Augustin Landier, 2002, The Perverse Effects of Partial Labour Market Reform: Fixed-Term Contracts in France, Economic Journal 112(480), F214F244.

Booth, Alison L., Juan J. Dolado, and Jeff Frank, 2002a, Introduction: Symposium on Temporary Work, Economic Journal 112(480), F181-F189.

Booth, Alison L., Marco Francesconi and Jeff Frank, 2002b, Temporary Jobs: Stepping Stones or Dead Ends?, Economic Journal 112(480), F189-F213.

Booth, Alison L., Marco Francesconi and Jeff Frank, 2002c, Labour as a Buffer: Do Temporary Workers Suffer? IZA Discussion Paper No. 673, IZA Bonn / Germany.

Cahuc, Pierre and Fabien Postel-Vinay, 2002, Temporary Jobs, Employment Protection and Labor Market Performance, Labour Economics 9(1), 63-91.

Dolado, Juan J., Carlos Garcia-Serrano, and Juan F. Jimeno, 2002, Drawing Lessons from the Boom of Temporary Jobs in Spain, Economic Journal 112(480), F270-F295.

Gibbons, Robert and Kevin J. Murphy, 1992, Optimal Incentive Contracts in the Presence of Career Concerns: Theory and Evidence, Journal of Political Economy 100(3), 468505 .

Holmlund, Bertil and Donald Storrie, 2002, Temporary Work in Turbulent Times: The Swedish Experience, Economic Journal 112(480), F245-F269.

Ichino, Andrea and Regina T. Riphahn, 2001, The Effect of Employment Protection on Worker Effort: A Comparison of Absenteeism During and After Probation, IZA Discussion Paper No. 385, IZA Bonn / Germany.

Jimeno, Juan Francisco and Luis Toharia Cortes, 1996, Effort, Absenteeism, and Fixed Term Employment Contracts, Revista Espanola de Economia 13(1), 105-119.

Johannson, Per and Mårten Palme, 1996, Do Economic Incentives Affect Work Absence? Empirical Evidence Using Swedish Micro Data, Journal of Public Economics 59(2), 195-218. 
Johannson, Per and Mårten Palme, 2002, Assessing the Effect of Public Policy on Worker Absenteeism, Journal of Human Resources 37(2), 381-409.

Lazear, Edward P. and Sherwin Rosen, 1990, Male-Female Wage Differentials in Job Ladders, Journal of Labor Economics 8(1, pt.2), S106-S123.

Morris, Michael and Alexander Vekker, 2001, An Alternative Look at Temporary Workers, Their Choices, and the Growth in Temporary Employment, Journal of Labor Research 22(2), 373-390.

Nagin, Daniel S., James B. Rebitzer, Seth Sanders, and Lowell J. Taylor, 2002, Monitoring, Motivation, and Management: The Determinants of Opportunistic Behavior in a Field Experiment, American Economic Review 92(4), 850-873.

OECD (Organisation for Economic Co-operation and Development), 1999, Employment Outlook, Paris.

OECD (Organisation for Economic Co-operation and Development), 2002, Employment Outlook, Paris.

Riphahn, Regina T. and Anja Thalmaier, 2001, Behavioral Effects of Probation Periods: An Analysis of Worker Absenteeism, Jahrbücher für Nationalökonomie und Statistik 221(2), 179-201.

Segal Lewis M. and Daniel G. Sullivan, 1997, The Growth of Temporary Services Work, Journal of Economic Perspectives 11(2), 117-136. 
Table 1: Worker Characteristics by Type of Contract (in percent of column total)

\begin{tabular}{lcc}
\hline & Permanent & Temporary \\
\hline Sociodemographic Characteristics & & \\
Agegroup 16-25 & 9.63 & 27.66 \\
Agegroup 26-40 & 47.54 & 46.48 \\
Agegroup 41-65 & 42.83 & 25.85 \\
Female & 30.48 & 42.33 \\
Married & 49.70 & 31.75 \\
Foreigner & 16.15 & 22.37 \\
Health Problems & 1.35 & 1.21 \\
Education None or basic & 12.17 & 15.00 \\
Education Medium & 55.79 & 37.31 \\
Education Advanced School & 5.75 & 13.26 \\
Education Adv. Vocational Training & 17.13 & 7.57 \\
Education Academic & 9.15 & 26.86 \\
Employment Characteristics & & \\
Firmsize 1-11 employees & & \\
Firmsize 20-99 employees & 28.57 & 29.81 \\
Firmsize $>$ 99 employees & 29.41 & 24.45 \\
Firmsize - Missing information & 40.30 & 39.99 \\
Tenure $<$ 5 years & 1.71 & 5.76 \\
Tenure 5-15 years & 40.12 & 78.83 \\
Tenure $>15$ years & 36.40 & 12.32 \\
\hline Number of observations & 23.49 & 8.84 \\
\hline
\end{tabular}

Table 2: Unpaid Overtime Work and Absenteeism by Type of Contract and Sex (in percent)

\begin{tabular}{|c|c|c|c|c|c|c|c|}
\hline & \multicolumn{2}{|c|}{ Contract } & \multicolumn{5}{|c|}{ Type of Temporary Contract } \\
\hline & $\begin{array}{c}\text { Perma- } \\
\text { nent }\end{array}$ & $\begin{array}{l}\text { Tem- } \\
\text { porary }\end{array}$ & $\begin{array}{l}\text { Seasonal } \\
\& \text { Casual }\end{array}$ & $\begin{array}{c}\text { Public } \\
\text { Program }\end{array}$ & Internship & Advanced & $\begin{array}{c}\text { Missing } \\
\text { Information }\end{array}$ \\
\hline \multicolumn{8}{|c|}{ A. Unpaid Overtime Work } \\
\hline All & 20.62 & 27.66 & 17.62 & 8.99 & 22.33 & 32.71 & 32.43 \\
\hline Males & 21.94 & 30.43 & 14.52 & 7.02 & 32.22 & 35.90 & 34.09 \\
\hline Females & 17.62 & 23.89 & 22.09 & 12.50 & 15.20 & 27.86 & 30.00 \\
\hline \multicolumn{8}{|l|}{ B. Absence } \\
\hline All & 1.15 & 0.80 & 0.95 & 2.25 & 0.47 & 0.55 & 2.70 \\
\hline Males & 1.06 & 0.58 & 0.81 & 1.75 & 0.00 & 0.55 & 0.00 \\
\hline Females & 1.35 & 1.11 & 1.16 & 3.13 & 0.80 & 0.56 & 6.67 \\
\hline $\begin{array}{l}\text { Number of } \\
\text { observations }\end{array}$ & 32,452 & 1,493 & 210 & 89 & 215 & 905 & 74 \\
\hline
\end{tabular}


Table 3: Descriptive Statistics of Explanatory Variables

\begin{tabular}{|c|c|c|c|c|}
\hline \multirow{2}{*}{ Variable } & \multicolumn{2}{|c|}{ Male } & \multicolumn{2}{|c|}{ Female } \\
\hline & Mean & Std.Dev. & Mean & St.Dev. \\
\hline \multicolumn{5}{|l|}{ Key Explanatory Variables } \\
\hline Temporary Contract $(0 / 1)$ & 0.037 & 0.188 & 0.060 & 0.238 \\
\hline Temp. Contract Seasonal \& Casual (0/1) & 0.005 & 0.073 & 0.008 & 0.090 \\
\hline Temp. Contract Public Program (0/1) & 0.002 & 0.049 & 0.003 & 0.055 \\
\hline Temp. Contract Internship (0/1) & 0.004 & 0.062 & 0.012 & 0.108 \\
\hline Temp. Contract Advanced (0/1) & 0.023 & 0.151 & 0.034 & 0.181 \\
\hline Temp. Contract - Missing information $(0 / 1)$ & 0.002 & 0.043 & 0.003 & 0.053 \\
\hline \multicolumn{5}{|l|}{ Sociodemographic Characteristics } \\
\hline Age in years & 40.211 & 10.862 & 36.930 & 11.471 \\
\hline Agegroup 16-25 (0/1) & 0.073 & 0.260 & 0.174 & 0.379 \\
\hline Agegroup 26-40 (0/1) & 0.479 & 0.450 & 0.467 & 0.499 \\
\hline Agegroup 41-65 (0/1) & 0.448 & 0.497 & 0.359 & 0.480 \\
\hline Married $(0 / 1)$ & 0.597 & 0.491 & 0.250 & 0.433 \\
\hline Foreigner $(0 / 1)$ & 0.163 & 0.369 & 0.167 & 0.373 \\
\hline Health Problems ${ }^{1)}(0 / 1)$ & 0.014 & 0.117 & 0.012 & 0.111 \\
\hline Education None or basic $(0 / 1)$ & 0.103 & 0.304 & 0.167 & 0.373 \\
\hline Education Medium (0/1) & 0.536 & 0.499 & 0.580 & 0.494 \\
\hline Education Advanced School (0/1) & 0.043 & 0.203 & 0.100 & 0.301 \\
\hline Education Adv. Vocational Training (0/1) & 0.207 & 0.405 & 0.077 & 0.267 \\
\hline Education Academic (0/1) & 0.110 & 0.314 & 0.074 & 0.262 \\
\hline \multicolumn{5}{|l|}{ Employment Characteristics } \\
\hline Firmsize $1-11(0 / 1)$ & 0.272 & 0.445 & 0.318 & 0.466 \\
\hline Firmsize $20-99(0 / 1)$ & 0.304 & 0.460 & 0.265 & 0.442 \\
\hline Firmsize $>99(0 / 1)$ & 0.411 & 0.492 & 0.384 & 0.486 \\
\hline Firmsize - Missing information $(0 / 1)$ & 0.013 & 0.113 & 0.032 & 0.177 \\
\hline Tenure (in years) & 10.495 & 9.715 & 7.552 & 7.849 \\
\hline Tenure $<5$ years $(0 / 1)$ & 0.379 & 0.485 & 0.507 & 0.500 \\
\hline Tenure $5-15$ years $(0 / 1)$ & 0.361 & 0.480 & 0.337 & 0.473 \\
\hline Tenure $>15$ years $(0 / 1)$ & 0.261 & 0.439 & 0.157 & 0.363 \\
\hline Number of observations & \multicolumn{2}{|c|}{23,423} & \multicolumn{2}{|c|}{10,522} \\
\hline
\end{tabular}

Note: ${ }^{1)}$ Descriptive statistics are calculated based on non-missing indicators only. The missing values for the first three surveys, when the question was not asked, were set to zero. 
Table 4: Probit Estimates of the Determinants of Effort Choice

\begin{tabular}{|c|c|c|c|c|}
\hline & \multicolumn{2}{|c|}{ Unpaid Overtime Work } & \multicolumn{2}{|c|}{ Absence } \\
\hline & Coeff. & St.Err. & Coeff. & St.Err. \\
\hline Temporary Contract & 0.241 & $0.065 * * *$ & -0.132 & 0.114 \\
\hline \multicolumn{5}{|l|}{ Sociodemographic Characteristics } \\
\hline Agegroup 26-40 & 0.008 & 0.056 & 0.051 & 0.079 \\
\hline Agegroup 41-65 & 0.320 & $0.063 * * *$ & 0.246 & $0.083 * * *$ \\
\hline Female & -0.285 & $0.042 * * *$ & 0.167 & $0.053 * * *$ \\
\hline Married & 0.186 & $0.036 * * *$ & 0.044 & 0.047 \\
\hline Education Medium & 0.291 & $0.063 * * *$ & -0.182 & $0.054 * * *$ \\
\hline Education Advanced School & 1.049 & $0.086 * * *$ & -0.284 & $0.112 * *$ \\
\hline Education Adv. Vocational Training & 0.984 & $0.072 * * *$ & -0.361 & $0.081 * * *$ \\
\hline Education Academic & 1.538 & $0.080 * * *$ & -0.595 & $0.130 * * *$ \\
\hline Health Problems & -0.231 & $0.131 *$ & 1.058 & $0.082 * * *$ \\
\hline Foreigner & -0.298 & $0.050 * * *$ & 0.164 & $0.051 * * *$ \\
\hline \multicolumn{5}{|l|}{ Employment Characteristics } \\
\hline Tenure (in years/10) & -0.016 & 0.044 & -0.068 & 0.060 \\
\hline Tenure $^{2}\left(\right.$ in years $\left.{ }^{2} / 100\right)$ & 2.326 & $1.249 *$ & 1.301 & 1.647 \\
\hline Firmsize 20-99 employees & -0.144 & $0.038 * * *$ & 0.035 & 0.053 \\
\hline Firmsize $>99$ employees & -0.328 & $0.039 * * *$ & -0.007 & 0.055 \\
\hline Firmsize Missing information & -0.150 & 0.105 & 0.109 & 0.128 \\
\hline \multicolumn{5}{|l|}{ Fixed Effect Controls } \\
\hline Occupation dummies & Yes & $* * *$ & Yes & $* * *$ \\
\hline Industry dummies & Yes & $-\quad * * *$ & Yes & $-\quad * *$ \\
\hline Yearly dummies & Yes & - & Yes & - \\
\hline Rho & 0.628 & $0.011 * * *$ & - & - \\
\hline Estimator & \multicolumn{2}{|c|}{ Random Effects Probit } & \multicolumn{2}{|c|}{ Probit, robust St.Errors } \\
\hline Log Likelihood & \multicolumn{2}{|l|}{$-13,427.2$} & \multicolumn{2}{|l|}{$-1,926.7$} \\
\hline Predicted Effect of Temp. Contract & \multicolumn{2}{|l|}{60.49} & \multicolumn{2}{|l|}{-30.94} \\
\hline Number of observations & \multicolumn{2}{|l|}{33,945} & \multicolumn{2}{|l|}{33,945} \\
\hline \multicolumn{5}{|l|}{ Note: $1 . * * *, * *$ and $*$ re } \\
\hline
\end{tabular}

3. The asterisks for the fixed effects controls indicate the joint significance of these measures. 
Table 5: Random Effects Probit Estimates of the Determinants of Unpaid Overtime Work: Heterogeneous Effects of Temporary Contracts

\begin{tabular}{|c|c|c|}
\hline & Coeff. & St.Err. \\
\hline Permanent Contract (Reference) & - & - \\
\hline Temporary Contract Seasonal \& Casual & 0.212 & 0.176 \\
\hline Temporary Contract Public Program & -0.473 & 0.291 \\
\hline Temporary Contract Internship & 0.160 & 0.162 \\
\hline Temporary Contract Advanced & 0.296 & $0.078 * * *$ \\
\hline Temporary Contract - Missing information & 0.487 & $0.241 * *$ \\
\hline Rho & 0.627 & $0.011 * * *$ \\
\hline Estimator & \multicolumn{2}{|c|}{ Random Effects Probit } \\
\hline Log Likelihood & \multicolumn{2}{|c|}{$-13,423.0$} \\
\hline P-Value for Test of Joint Sign. of Presented Coeff. & \multicolumn{2}{|c|}{0.001} \\
\hline Number of observations & \multicolumn{2}{|c|}{33,945} \\
\hline
\end{tabular}

Note: $\quad 1 .{ }^{* * *}, * *$ and $*$ represent statistical significance at the 1,5 and 10 percent level, respectively. 2. The model controls for the same set of covariates as in Table 4 . 
Table 6: Random Effects Probit Estimates of the Determinants of Unpaid Overtime Work: Differences Across the Sexes

\begin{tabular}{|c|c|c|c|c|}
\hline & \multicolumn{2}{|c|}{ (1) } & \multicolumn{2}{|r|}{ (2) } \\
\hline & Coeff. & St.Err. & Coeff. & St.Err. \\
\hline Temporary Contract & 0.278 & $0.083 * * *$ & - & - \\
\hline Female & -0.279 & $0.043 * * *$ & -0.280 & $0.043 * * *$ \\
\hline Temporary Contract $*$ Female & -0.092 & 0.128 & - & - \\
\hline Temporary Contract Seasonal \& Casual & - & - & -0.076 & 0.250 \\
\hline Temporary Contract Public Program & - & - & -0.750 & $0.374 * *$ \\
\hline Temporary Contract Internship & - & - & 0.492 & $0.228 * *$ \\
\hline Temporary Contract Advanced & - & - & 0.360 & $0.098 * * *$ \\
\hline Temporary Contract - Missing information & - & - & 0.483 & 0.312 \\
\hline Temporary Contract Seasonal \& Casual * Female & - & - & 0.607 & $0.354 *$ \\
\hline Temporary Contract Public Program * Female & - & - & 0.784 & 0.599 \\
\hline Temporary Contract Internship * Female & - & - & -0.664 & $0.323 * *$ \\
\hline Temporary Contract Advanced $*$ Female & - & - & -0.167 & 0.158 \\
\hline Temporary Contract - Missing information * Female & - & - & 0.007 & 0.491 \\
\hline Rho & 0.628 & $0.011 * * *$ & 0.627 & $0.011 * * *$ \\
\hline Estimator & Randor & fects Probit & Randor & ffects Probit \\
\hline Log Likelihood & $-13,426$ & & $-13,41^{\prime}$ & \\
\hline P-Value for Test of Joint Sign. of Interaction Effects & - & & 0.072 & \\
\hline Number of observations & 33,945 & & 33,945 & \\
\hline
\end{tabular}

Note: $1 . * * *, * *$ and $*$ represent statistical significance at the 1,5 and 10 percent level, respectively.

2. The models control for the same set of regressors as in the specifications in Table 4. 
Table 7: Random Effects Probit Estimates of the Determinants of Unpaid Overtime Work in Period t: Dynamic Effects of Temporary Contracts

\begin{tabular}{|c|c|c|c|c|}
\hline & & \\
\hline & Coeff. & St.Err. & Coeff. & St.Err. \\
\hline Reference: Permanent Contract in $\mathrm{t}-1$ and in $\mathrm{t}$ & - & - & - & - \\
\hline Temporary Contract in $\mathrm{t}$ & 0.215 & $0.112 *$ & - & - \\
\hline Permanent Contract in $\mathrm{t}$ and Temporary in $\mathrm{t}-1$ & 0.127 & 0.123 & - & - \\
\hline Reference: Permanent Contract in $\mathrm{t}$ & - & - & - & - \\
\hline Temporary Contract in $\mathrm{t}$ and Temporary Contract in $\mathrm{t}+1$ & - & - & 0.646 & $0.159 * * *$ \\
\hline Temporary Contract in $\mathrm{t}$ and Permanent Contract in $\mathrm{t}+1$ & - & - & 0.255 & $0.199 *$ \\
\hline Rho & 0.667 & $0.014 * * *$ & 0.665 & $0.015 * * *$ \\
\hline Estimator & \multicolumn{2}{|c|}{ Random Effects } & \multicolumn{2}{|c|}{ Random Effects } \\
\hline Log Likelihood & \multicolumn{2}{|c|}{$-7,074.4$} & \multicolumn{2}{|c|}{$-7,085.2$} \\
\hline Number of Observations & \multicolumn{2}{|c|}{18,037} & \multicolumn{2}{|l|}{18,037} \\
\hline
\end{tabular}

Note: $1 .{ }^{* * *},{ }^{* *}$ and $*$ represent statistical significance at the 1,5 and 10 percent level, respectively.

2. The models control for the same set of regressors as in the specifications in Table 4.

3. Due to controls for lagged and lead variables the number of observations declined compared to prior estimations. 


\section{IZA Discussion Papers}

No.

Author(s)

W. Schnedler

766

767

768

769

770

771

772

773

774

775

776

777

778

779

780
D. N. F. Bell

R. A. Hart

P. Carneiro

K. T. Hansen

J. J. Heckman

J. J. Heckman

S. Navarro-Lozano

L. Flood

J. Hansen

R. Wahlberg

A. Heitmueller

A. Calvó-Armengol

Y. Zenou

E. Patacchini

Y. Zenou

A. Heitmueller

A. Constant

D. S. Massey

J. J. Heckman

L. J. Lochner

P. E. Todd

L. Arranz-Aperte

A. Heshmati

A. Falk

M. Kosfeld

F. Galindo-Rueda

M. Biewen

A. Engellandt

R. T. Riphahn
Title

Area

Date

On the Prudence of Rewarding A While Hoping

5

for $B$

How Important Is Guaranteed or Institutionalised

Overtime?

Estimating Distributions of Treatment Effects

6

$04 / 03$

$04 / 03$

with an Application to the Returns to Schooling

and Measurement of the Effects of Uncertainty

on College Choice

Using Matching, Instrumental Variables and

6

Control Functions to Estimate Economic Choice

Models

Household Labor Supply and Welfare

3

Participation in Sweden

Coordination Failures in Network Migration

$04 / 03$

Job Matching, Social Network and

5

05/03

Word-of-Mouth Communication

Search Intensity, Cost of Living and Local

3

05/03

Labor Markets in Britain

05/03

Evidence from the BHPS

Labor Market Segmentation and the Earnings of 1

German Guestworkers

Fifty Years of Mincer Earnings Regressions

5

05/03

Determinants of Profit Sharing in the Finnish 2

Corporate Sector

It's all about Connections: Evidence on Network

6

Formation

Employer Learning and Schooling-Related

5

05/03

Statistical Discrimination in Britain

Who Are the Chronic Poor? Evidence on the

1

05/03

Extent and the Composition of Chronic Poverty in Germany

Temporary Contracts and Employee Effort

1

05/03

An updated list of IZA Discussion Papers is available on the center's homepage www.iza.org. 